\title{
POTENTIAL EFFECTS OF FINANCE 4.0 ON THE EMPLOYMENT IN EAST AFRICA
}

\author{
Imre VIDA ${ }^{1}$, PhD Student \\ Szent István University, Hungary \\ Endre SPALLER ${ }^{2}$, PhD Student \\ Széchenyi István University, Hungary \\ László VASA ${ }^{3}$, Habilitation in economics, Research Professor \\ Széchenyi István University, Hungary
}

DOI: https://doi.org/10.36004/nier.es.2020.2-03

JEL Classification: E24, F65, G21, G23, N17, N37

UDC: $336+331.57(06)$

\section{ABSTRACT}

Two of the five fastest-growing economies in the world were in the East African region in 2019. The region's share within the economic growth of Africa rose from less than 20\% in 2018 to more than $32 \%$ in 2019. Despite the difficulties in 2020 the eastern part of Africa seems to be keeping its status as the continent's fastest-growing region. Digitalization and the connected structural transformation is one of the main drivers of growth in the services sector worldwide. In this study we analyze the status and movements of industry 4.0 and Finance 4.0 developments and their effects on the employment in the East African region. We found three main approaches based on the literature sources on Africa's future industrial development ways. In case of finance 4.0, countries like Uganda or Kenya reached considerable results in financial inclusion; thus, East African economies and societies now have an improved access to international financial markets. Another significant development is East Africa's status as global leader in mobile money services, increasing broad access to financial services. With the help of digital solutions, entrepreneurs and businesses can reconsider their business models which can be more competitive, sustainable, and better connected to other sectors of the economy. In this paper we investigated the macro- and micro-level effects of the digitalization on the employment and identified the possible scenarios. Our conclusion is that with affordable and stable finance 4.0 solutions and a strong institutional framework, East African enterprises can reduce poverty, increase employment and stimulate inclusive growth.

Keywords: finance 4.0, East-Africa, employment, financial inclusion, industry 4.0, mobile money.

Două dintre cele cinci economii cu cea mai rapidă creștere din lume s-au aflat în regiunea Africii de Est în 2019. Cota regiunii în creșterea economică a Africii a crescut de la mai puțin de $20 \%$ în 2018 la peste 32\% în 2019. În ciuda dificultăților din 2020 partea de est a Africii pare să-și păstreze statutul de regiune cu cea mai rapidă creștere a continentului. Digitalizarea și transformarea structurală conectată este unul dintre principalii factori de creștere în sectorul serviciilor la nivel mondial. În acest studiu analizăm situația și mișcările dezvoltărilor industriei 4.0 și Finanțelor 4.0 și efectele acestora asupra ocupării forței de muncă în regiunea Africii de Est. Au fost identificate trei abordări principale bazate pe surse de literatură privind viitoarele căi de dezvoltare industrială ale Africii. În cazul finanțării 4.0, țările ca Uganda sau Kenya au atins rezultate considerabile în ceea ce privește incluziunea financiară; astfel, economiile și societățile din Africa de Est au acum un acces îmbunătățit la piețele financiare internaţionale. $O$ altă evoluție semnificativă este statutul Africii de Est ca lider global în servicii de bani mobili, sporind accesul larg la servicii financiare. Cu ajutorul soluțiilor digitale, antreprenorii și întreprinderile își pot reconsidera modelele de afaceri care pot fi mai competitive, durabile și mai bine conectate la alte sectoare ale economiei. În această lucrare am investigat efectele la nivel macro și micro

\footnotetext{
${ }^{1}$ ID ORCID 0000-0001-8089-9703 «e-mail: info@vidaimre.hu

${ }^{2}$ ID ORCID 0000-0002-9262-3365 e-mail: spaller.endre@kifu.gov.hu

3 ID ORCID 0000-0002-3805-0244 «e-mail: vasalaszlo@gmail.com
} 
ale digitalizării asupra ocupării forței de muncă și am identificat scenariile posibile. Concluzia noastră este: cu soluții de finanțare 4.0 accesibile și stabile și un cadru instituțional puternic, întreprinderile din Africa de Est pot reduce sărăcia, pot crește ocuparea forței de muncă și pot stimula o creștere favorabilă incluziunii.

Cuvinte-cheie: finanțe 4.0, Africa de Est, ocuparea forței de muncă, incluziune financiară, industrie 4.0, bani mobili.

Две из пяти самых быстрорастущих экономик мира находились в регионе Восточной Африки в 2019 году. Доля региона в экономическом росте Африки выросла с менее, чем на 20\% в 2018 году до более, чем $32 \%$ в 2019 году. Несмотря на трудности в 2020 году, восточная часть Африки, сохраняет свой статус самого быстрорастущего региона континента. Цифровизация и связанная структурная трансформация являются одними из основных драйверов роста в секторе услуг во всем мире. В этом исследовании мы анализируем состояние и динамику развития Индустрии 4.0 и Финансов 4.0, а также их влияние на занятость в регионе Восточной Африки. Мы нашли три основных подхода на основе литературных источников о будущих путях промышленного развития Африки. В случае «Финансы 4.0» такие страны, как Уганда или Кения, достигли значительных результатов в финансовой доступности; таким образом, экономика и общества Восточной Африки теперь имеют улучшенный доступ к международным финансовым рынкам. Еще одно важное событие - это статус Восточной Африки как мирового лидера в сфере услуг мобильных денег, что расширило широкий доступ к финансовым услугам. С помощью цифровых решений предприниматели и предприятия могут пересмотреть свои бизнес-модели, которые могут стать более конкурентоспособными, устойчивыми и лучше связанными с другими секторами экономики. В этой статье мы исследовали макро- и микроуровневое влияние цифровизации на занятость и определили возможные сценарии. Мы пришли к выводу, что с помощью доступных и стабильных финансовых решений 4.0 и прочной институциональной базы восточноафриканские предприятия могут сократить бедность, увеличить занятость и стимулировать инклюзивный рост.

Ключевые слова: финансы 4.0, Восточная Африка, занятость, финансовая доступность, промышленность 4.0, мобильные деньги.

\section{INTRODUCTION}

In 2019, two of the five fastest-growing economies in the world were in the East African region (Ethiopia and Rwanda). Based on the analysis of the prestigious Brookings Institute, this region's share within the economic growth of Africa rose from less than $20 \%$ in 2018 to more than $32 \%$ in 2019 [23]. Even though the year 2020 seems to be a kind of disaster in terms of economic performance, the African Development Bank (AfDB) forecasts that the eastern part of Africa is keeping its status as the continent's fastest-growing region [2]. According to the AfDB, agriculture's contribution to the region's gross domestic product decreased from $33.4 \%$ in the early 2000 s to $28.3 \%$ in 2018. Instead, the vibrant and fast-growing services sector performed more than half $(53.8 \%)$ of the East Africa's GDP. This shift in the economies generates new and restructured employment opportunities. According to the Africa Prosperity Report by Legatum Institute [26], the number of employment opportunities in East Africa's services sector increased to more than double between 2000 and 2020.

Digitalization and the connected structural transformation is one of the main drivers of growth in the services sector worldwide. The World Bank estimates that connecting every African business, individual and government to digital technologies in the frame of the Single Digital Market by 2030 can boost growth by up to $2 \%$ per year and reduce poverty by $1 \%$ per year [44].

\section{LITERATURE REVIEW}

\section{Current status of Industry 4.0 in East Africa}

We can identify three main approaches in the literature on Africa's future industrial development ways. Technological revolution plays a crucial role in each of these concepts: 1) the technological change is too fast and complex for African countries to benefit from it promptly; at least 
15 years needed for completing the necessary investments and developing the appropriate business ecosystems in the continent [6];2) technological revolution is changing the nature and base of manufacturing and services, making services sector the focal point for structural adjustments [32]; 3 ) the new and emerging technological developments encourage and upgrade the African manufacturing with the help of high-tech start-up firms [29].

The industry 4.0 implementation in East Africa is based mainly on transcontinental efforts [3]. In Africa, the commitment to industry 4.0 can be identified on the different program initiatives launched recently: "Smart Africa", "One Africa Network" and "EU-AU Digital Task force". Smart Africa program focusing on whole Africa, was initiated by the East African Community (EAC) in 2013. Industry 4.0 demands upgraded employee skills and competencies, including ICT knowledge, inter-, trans-, and multidisciplinary competencies, and special personal qualities. Moreover, in addition of industry 4.0 digitalization base, knowledge and skills in ICT sector are necessary as these are the ground for the digital transformation. However, the poor ICT infrastructural environment in East African countries is therefore one of the major challenges which are making barriers for governments to adopt the industry 4.0 in a rapid way [28]. So, ICT adoption among the EAC countries (Rwanda, Kenya, Uganda, Tanzania, Burundi, and South Sudan) was realized parallel with industry 4.0.

In 2012, the East African Community (EAC), covering Burundi, Kenya, Rwanda, South Sudan, Tanzania and Uganda, announced its 2012-2032 Industrialisation Policy. The strategy is targeting to establish a market-driven, competitive and balanced industrial sector which relies on the advantages of East Africa [11].

Kenya is one of the few countries in Africa that achieved the lower middle-income status already [40]. In the business terminology of the new digital economy Kenya is called Africa's "Silicon Savanah" [24]. The reason for this analogy is the presence of a very strong and well-focused ICT policy with its flagship program Vision 2030. Moreover, the advanced technology in the mobile money system such as M-Pesa is a real pioneer in this field. The M-Pesa (means mobile money) revolution has created Kenya's digital space and positioned the country ahead of other developing countries regarding the implementation, use and development of digital technology [35]. M-Pesa is a mobile payment platform introduced and started in 2007 as a cooperation of Safaricom, Commercial Bank of Africa, and commercial banks in Kenya [31]. Another remarkable milestone in the Kenyan digital industry was the successful development of a virtual money savings platform called "M-Shwari" which has been spread out in the whole East African region, with "M-Pawa" in Tanzania and "Mokash" in Uganda and Rwanda. Within the Kenyan ICT policy framework, a Government Digital Payments Taskforce was launched, the eCitizen. In spite of the strong and committed ICT policy of Kenya, the implementation strategy and details of the industry 4.0 is not clear yet.

Rwanda is one of the three African countries (besides Morocco and South Africa) that started to develop industry 4.0 strategy alongside its ICT policies and created technology centres [12]. The Rwandese government established the "Centre for the Internet of Things" in partnership with Inmarsat, the global mobile satellite communications provider [41]. The initiative's focus is on helping the learning capabilities and skills of students, developing IoT prototypes and to conducting academic research in prospective IoT solutions. In addition, it tries to speed up the implementation of the IoT and smart city results. The country's first ICT policy framework was the SMART Rwanda Master Plan 2015-2020; some initiatives have been generated and realized by both the government and private sector. The major ICT innovative initiatives of Uganda are: Rwanda's ICT Hub Strategy 2024, Digital Ambassadors Program, IREMBO platform, Kigali Innovation City. The clever ICT policy has significantly contributed to the integration of Rwanda's cultural and creative industry to the global economic systems [22]. The new "Made in Rwanda" policy is an all-inclusive strategic plan targeting the stimulation of competitiveness by improving the domestic market by the value chain development. These initiatives serve the main goal to develop Rwanda into an upper middle-income country by 2035 and higher income country by 2050 [29]. This new policy has the capacity to push and promote industry 4.0 adoption and implementation in the country.

Uganda developed its strategic plan "Vision 2040" where the main focus is on industrialization. Despite of the clear and set macro vision, the country's national industrial policy still does not prioritize manufacturing, meaning the manufacturing sector remains less competitive with mainly 
focusing on agriculture related processing and low-value manufacturing [13]. The government of Uganda seems to be committed for developing a digital vision for the country and elaborated the Digital Uganda Vision (DUV) program. The DUV is a comprehensive framework that is driven by from the Vision 2040 macro vision and provides a complete set of ICT policies [17]. This policy package is directed by the Ministry of ICT which was established specifically for supporting the growth and deployment of the ICT sector in Uganda. For ICT ministry staff special knowledge is provided on industry 4.0 technologies including as blockchain technologies, artificial intelligence, big data and cloud computing. Furthermore, the Blockchain Association of Uganda as non-governmental organization has been founded and the government related Nakawa Innovation ICT Hub has been established [34]. These developments demonstrate Uganda's commitment to the development of industry 4.0 related fields, however, there is still much to be done by Uganda to catch up with the mainstream.

Tanzania is doing serious efforts for improving its industrial sector's productivity and competitiveness. These steps are coordinated by the $5^{\text {th }}$ Phase of the Government Plan under in the frame of Vision 2025 strategic program [1]. Tanzania has a well-established ICT policy; however, concrete steps are still missing [36]. The potential positive impacts of ICT in Tanzanian context are predominantly in industrial agriculture and company business processes (Mwantinwa, 2019). Tanzania hosts the joint initiative of East African Community and the German Federal Ministry for Economic Cooperation and Development (BMZ), the Centre of Excellence for ICT in East Africa (CENIT@EA) which has been launched in 2019. The main aim of this Centre is to provide industry 4.0 relevant skills, capabilities, and knowledge for supporting the digital transformation. This initiative is essential for setting up well-based digital skills needed for the Tanzanian economy and society, therefore providing an appropriate environment and frame for industry 4.0 implementation.

Burundi and South Sudan. Due to the unstable political environment, these two East African countries have failed to take any steps towards developing their economy and society with the toolset of industry 4.0 [43], the development visions of these two countries are mainly focusing on peace and stability.

Table 1

\section{Strategic vision of the EAC member states}

\begin{tabular}{|c|c|c|}
\hline Member state & $\begin{array}{l}\text { Time } \\
\text { frame }\end{array}$ & Strategic vision \\
\hline Uganda & Vision 2040 & $\begin{array}{l}\text { Transform Ugandan society from peasant to a modern prosperous } \\
\text { country }\end{array}$ \\
\hline Kenya & Vision 2030 & $\begin{array}{l}\text { Globally competitive and prosperous Kenya with a high quality of } \\
\text { life }\end{array}$ \\
\hline Rwanda & $\begin{array}{l}\text { Vision } 2020 \\
\text { Vision } 2050 \\
\end{array}$ & $\begin{array}{l}\text { Become a middle-income country by } 2020 \\
\text { High standard of living }\end{array}$ \\
\hline Tanzania & Vision 2025 & $\begin{array}{l}\text { High quality of life anchored on peace, stability, unity, and good } \\
\text { governance; rule of law, resilient economy, and competitiveness }\end{array}$ \\
\hline South Sudan & Vision 2040 & Realizing freedom, equality, justice, peace, and prosperity for all \\
\hline Burundi & Vision 2025 & $\begin{array}{l}\text { Sustainable peace and stability and achievement of global } \\
\text { development commitments in line, Millennium Development Goals }\end{array}$ \\
\hline EAC & Vision 2050 & $\begin{array}{l}\text { Attain a prosperous, competitive, secure and politically united East } \\
\text { Africa }\end{array}$ \\
\hline
\end{tabular}

Source: [7].

It is obvious from the above status reports that all the EAC members have a strong ICT policy initiative except Burundi and South Sudan. Kenya and Rwanda are the most advanced. Table 2 demonstrates that the focus of ICT initiatives is mainly on governance and services rather than industry and agriculture. Concerning industry 4.0 initiatives, countries in East Africa perform a quite low level of readiness, with exception of Rwanda. 
Table 2

Initiatives in the EAC launched within the ICT policies

\begin{tabular}{|l|l|c|l|}
\hline \multirow{5}{*}{ Country } & \multicolumn{1}{|c}{ Initiatives } & Year & \multicolumn{1}{|c|}{ Funding } \\
& ICT4Agric & 2017 & - \\
\cline { 2 - 4 } & E-government (eTAX, mTrac, e-water) & - & Public \\
\cline { 2 - 4 } & Mobile money platform (MTN, Airtel) & 2009 & Public-private \\
\cline { 2 - 4 } & M-Pesa & 2007 & Private \\
\cline { 2 - 4 } & M-Shwari, M-Pawa, and Mokasa & 2012 & Private \\
\hline \multirow{5}{*}{ Kenya } & $\begin{array}{l}\text { Government Digital Payments Taskforce (eCitizen) } \\
\text { Tanzania }\end{array}$ & - & Public \\
\cline { 2 - 4 } & PRIMR (Primary Math and Reading) & 2011 & Public-private \\
\cline { 2 - 4 } & ICT4D or e-government agency & - & Public \\
\hline & E-transparency & 2009 & Public \\
\cline { 2 - 4 } & E-government strategy 2013 & 2013 & Public \\
\cline { 2 - 4 } & IREMBO e-government platform, one-stop e-government & 2015 & Public-private \\
\cline { 2 - 4 } & Digital Ambassadors Program (DAP) & 2019 & Public \\
\cline { 2 - 4 } & Kigali Innovation City (KIC) & 2016 & Public \\
\hline \multirow{5}{*}{ Rwanda } & Rwanda's ICT Hub Strategy 2024 & 2019 & Public \\
\cline { 2 - 4 } & Tap\&Go Smartcard & 2015 & Public-private \\
\cline { 2 - 4 } & Smart city Rwanda & 2019 & Public \\
\hline
\end{tabular}

Source: [39] [7].

\section{Fintech in East Africa}

Innovations in financial sector, often referred to as "FinTech", is transforming the global financial sector drastically. Since 2010, more than 50 billion USD has been invested in around 2,500 companies worldwide. This is meaning, FinTech revolution forces us to rethink the ways how we store, save, invest, lend, mobilize, spend, send and protect money [37].

FinTech is the key to supporting and accelerating significant improvements in financial system development experienced in the East African region over the last two decades. Liberalization in financial sector, monetary policy frameworks and instruments reforms, and developments in the institutional environment provided a considerable expansion of banking and financial activities and outputs. Some countries like Uganda or Kenya achieved significant progress in financial deepening and inclusion; as a result, this region now has an increased access to international financial markets. The arrival of pan-African banks resulted in a more intensive use of payment system tools such as debit and credit cards, but more remarkably, we can experience a robust growth in mobile payments in many East African countries - on a much different basis. However, financial systems and frameworks in East Africa still cope with several barriers and financial inclusion remains a problem, limiting the opportunities for further improvements in sustainable growth, employment, and poverty eradication [4].

FinTech is a major driver affecting the financial industry architecture in East Africa. New technologies were and are developed and implemented in East Africa with the potential to change the competitive circumstances in the financial sector. FinTech provokes traditional banking methods and creates efficiency advantages unfolding the financial services value chain. Nowadays, FinTech is evolving as a technological gamechanger in East Africa, upgrading financial inclusion and acting as a facilitator for innovation in other economic branches, e.g. agriculture and infrastructure [8].

East Africa achieved the status of the global leader in mobile money services, stimulating broad access to basic and advanced financial services. While-East Africa left behind the world in access to finance, several countries in the region are now forerunners globally. East Africa is the leader in mobile money implementation and use. With appropriate and for costumers attractive pricing strategy, advanced regulation frameworks, and a technically reliable network, Kenya is the most successful country in terms of the use of mobile money solutions [4]. 
The technological background for the FinTech products and services are well developed. The products and services developed in the field of FinTech rely on global technological innovations. These include the following innovations (based on [20]):

- Mobile access and the internet link consumers to each other (person-to-person transactions).

- Big data and artificial intelligence provide the availability and analysis of databases having billions of observations of transactions and attributes; these can be used to improve design and personalize financial products and services.

- Distributed ledger technology (DLT) means a type of networking of independent computers to record, share, and synchronize transactions instead of having a centralized database.

- Cryptography improves the safety of electronic transactions and is the basis for smart contracts based on cryptocurrencies.

\section{Mobile money developments in Sub-Saharan Africa}

Within Africa, the East African region is the absolutely forerunner and leader in mobile money development and usage. While the use of mobile money in sub-Saharan Africa is a real success story, there is a wide range of differences among the countries (Figure 1). East Africa did it well and created an infrastructure that built on the real demand for mobile financial services in sub-Saharan Africa. They realized that the limitations in terms of financial inclusion and lack of traditional banking retail units can be solved only via mobile money systems.

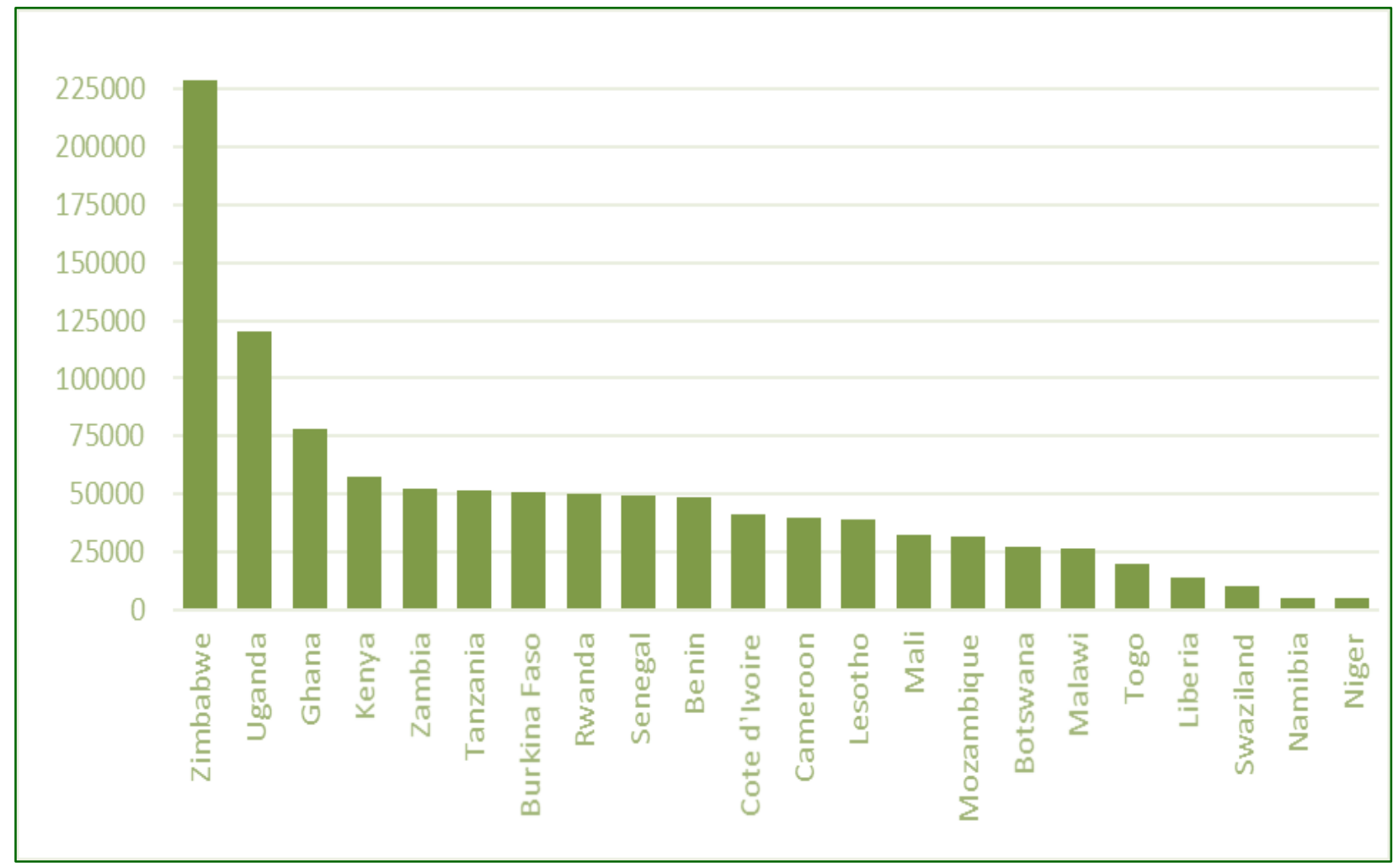

Figure 1. Mobile money developments in Sub-Saharan Africa (mobile money transactions per 100.000 adults, 2019)

Source: [21].

The countries in East Africa chose a telecom sector led regulatory scheme. In this solution, the telecommunication service provider cooperates with the financial regulatory body to develop the platform for mobile payments. This telecom-led model seems to be more successful in attracting clients than the bank-oriented model that is used by other sub-Saharan Africa countries. For regional distribution of alternative finance in Sub-Saharan Africa see Figure 2. 


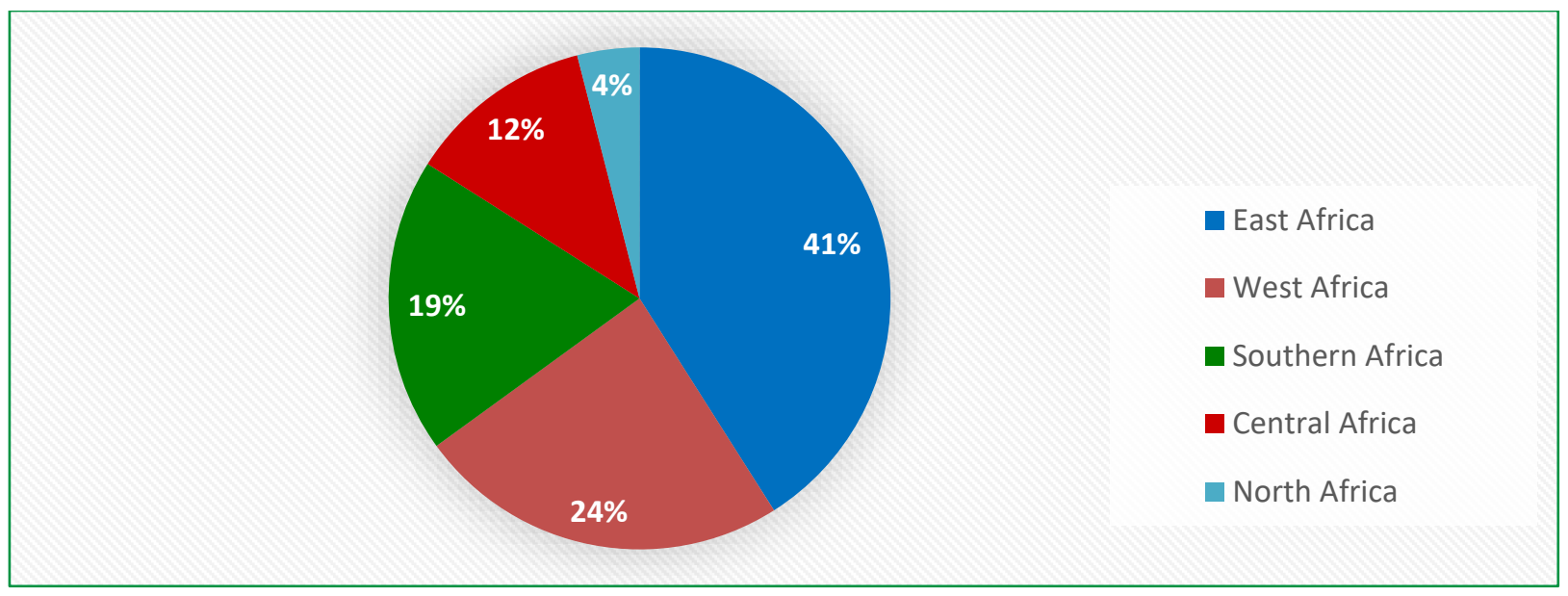

Figure 2. Regional distribution of alternative finance in Sub-Saharan Africa Source: [5].

East African countries decided to select a single telecom provider that owns a dominant market share, which assured the initial critical volume of required to put mobile money over the niche level (for mobile money providers see Table 3). So, instead of being a provider of a unique and exotic service with a small market share mobile money was getting the banking industry standard. In Kenya, mobile network operator Safaricom has a market share of around 70 percent; Vodacom in Tanzania has a share of around 50 percent. In Uganda, MTN Uganda and Airtel Uganda have almost the same market share ( 46 and 44 percent). This large market share makes it possible for most mobile money clients to use a single platform without having compatibility problems, From the other hand, this high market concentration raises competition law and consumer protection concerns.

Table 3

Mobile payment systems deployed in the EAC

\begin{tabular}{|c|c|c|c|c|c|c|}
\hline Service provider & Burundi & Kenya & Rwanda & S. Sudan & Tanzania & Uganda \\
\hline Africell Money & & & & & & $\mathrm{x}$ \\
\hline Airtel Money & & $\mathrm{x}$ & $\mathrm{x}$ & & & $\mathrm{x}$ \\
\hline BK mVISA & & & $\mathrm{x}$ & & & \\
\hline Dau-Pesa & & & & & $\mathrm{x}$ & \\
\hline EcoKash & $\mathrm{x}$ & & & & & \\
\hline EzeeMoney & & & & & & $\mathrm{x}$ \\
\hline ezyPersa & & & & & $\mathrm{x}$ & \\
\hline Leo Manoti & $\mathrm{x}$ & & & & & \\
\hline M-PESA & & $\mathrm{x}$ & & & & \\
\hline mHose & & & $\mathrm{x}$ & & & \\
\hline M-Sente & & & & & & $\mathrm{x}$ \\
\hline mCash & & & & & & $\mathrm{x}$ \\
\hline Micropay & & & & & & $\mathrm{x}$ \\
\hline MobiCash & $\mathrm{x}$ & $\mathrm{x}$ & $\mathrm{x}$ & & & \\
\hline MTN Mob'Money & & & $\mathrm{x}$ & & & $\mathrm{x}$ \\
\hline Orange Money & & $\mathrm{x}$ & & & & \\
\hline PAYG Platform & & $\mathrm{x}$ & & & & \\
\hline Tangaza Pesa & & $\mathrm{x}$ & & & & \\
\hline Tigo Cash & & & $\mathrm{x}$ & & & \\
\hline Tigo Pesa & & & & & $\mathrm{x}$ & \\
\hline Vodacom M-pesa & & & & & $\mathrm{x}$ & \\
\hline
\end{tabular}

Source: [19]. 
East African countries, especially in the East African Community, have national identification systems; these simplify and accelerate faster mobile payment adoption rates and allow more secure transactions.

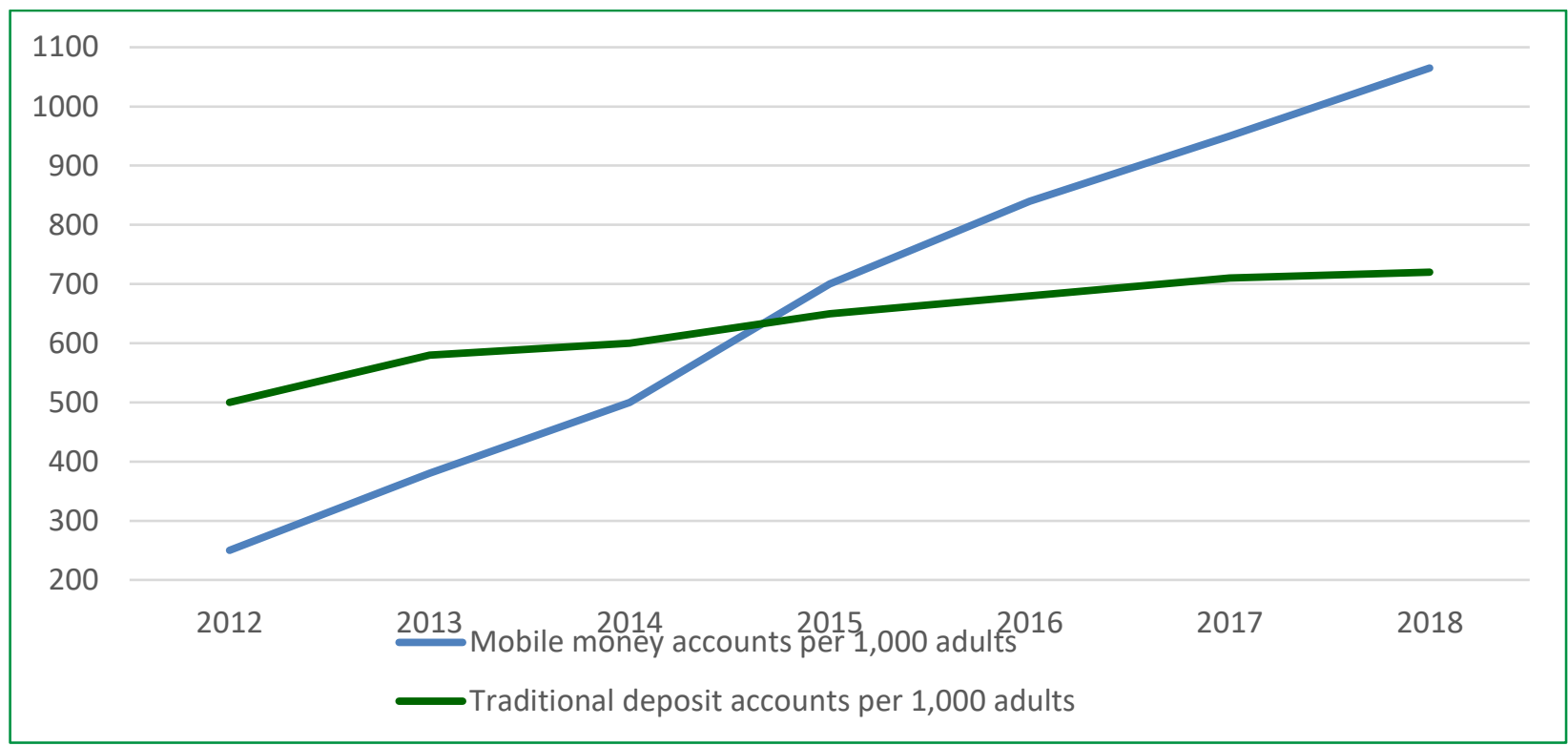

Source: [10].

Figure 3. Mobile Money versus traditional banking

Until recently, in East African economies, cash was dominant. In the region the credit cards and bank accounts penetration were low, traditional banking was limited. The mobile money revolution, initiated by the pioneer M-PESA and nowadays offered by several operators in the East African region, has transformed this situation dramatically and makes the ground for a new wave of financial inclusion that has now spread beyond the region and globally (Figure 3).

In the East African countries, there are significantly more mobile money accounts users than account holders with traditional banking institutions. The exceptions are South Sudan, where mobile money is not yet licensed, and Rwanda (Figure 4).

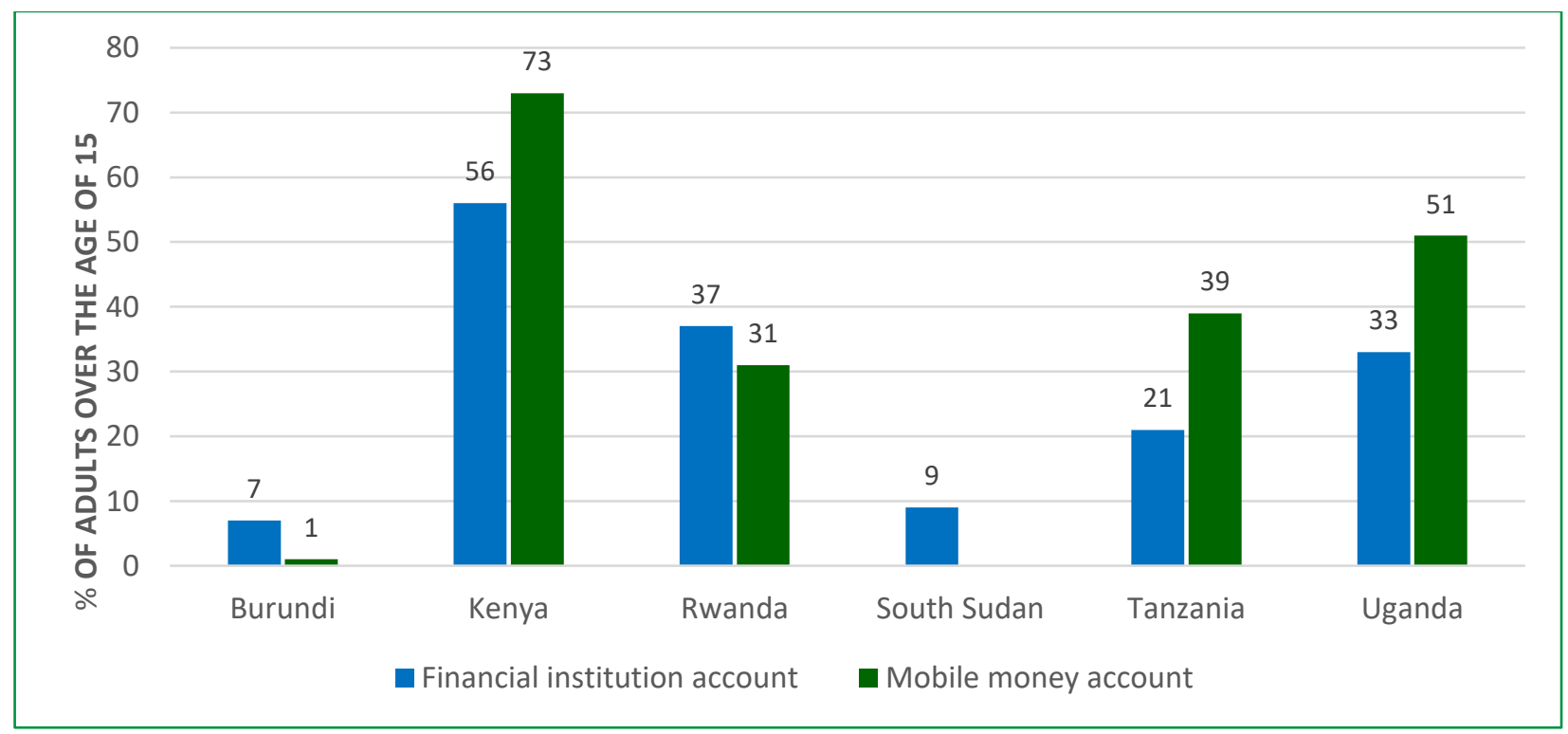

Figure 4. Penetration of financial institution accounts versus mobile money accounts Source: [10]. 
Nonetheless, digital payments' popularity rises rapidly in some countries: the use of digital payments among Ugandan adults is 55 percent and 79 percent in Kenya, however, remains limited in Burundi [10]. Moreover, there are several obstacles regarding international payments, including network interoperability and high transaction fees; this is a serious barrier for developing regional online services and the growth of e-commerce.

\section{METHODOLOGY}

Due to the lack of validated statistical sources and survey on this topic in the East African region, our research attempts to present the effects of the seemingly unstoppable expansion of finance 4.0 on employment in East Africa relying primarily on secondary data sources and a comparative analysis of the literature published in the topic. Using scenario analysis, we present these potential consequences at the micro and macro levels, as well as in terms of efficiency.

\section{RESULTS AND DISCUSSION}

\section{Impact of industry 4.0 on finance sector}

Finance 4.0, a subcategory of Industry 4.0 can support the grow of the emerging and developing economies by over 6\%, which takes about $\$ 3.7$ trillion by 2025 [27]. More than $37 \%$ of the foreign direct investment flowing to the developing countries was technology-intensive investment.

The fourth industrial revolution spread out to all industries with a rather positive impact. The financial services sector is also one of the sectors that is benefiting the power of industry 4.0 significantly. Banking, insurance, mortgage, forex, stocks, and many other financial sectors are booming due to the positive impetus of digital innovation and financial process automation.

According to [33], mobile based devices and tools are the new standard for banking activities. The developing regions like Africa are becoming the major driver of mobile banking in the world.

The blockchain technology based new crypto finance system will transform the financial sector in the near future. Taking these in consideration, we can summarize the impact of industry 4.0 on financial services as follows [38]:

- Global financial transactions have become much faster

- Financial service charges were getting much cheaper

- Significant decrease of financial institutes' operational costs

- 0-24 easy access to financial services

- Easy handling of upgraded financial systems and surfaces

- Expanded use of robotics and artificial intelligence

- A new era of marketing: more effective, more efficient, more targeted and tailored

- Effective and advanced customer service through bots at very low cost

- Reduced risks due to data-driven assessments

- More advanced business intelligence

- Greater user service experience

- Diminished opportunities for leakages in funds and projects

- More transparency and increased trust

- No chance for human errors in financial activities

- Rise of new business domains, e.g. FinTech, payment gateways

- Enhanced financial inclusion of the poor and disadvantaged people

- More effective use of available assets and money

- More efficient trading of stocks and forex

- Lowered number of scams and burglary

- Increased customer satisfaction

- Smart contracts powered by blockchain technology

Effects of finance 4.0 on the employment in East Africa

Digitalization's main benefit for economic growth is promoting inclusive finance and allowing the by banks not covered groups to join formal financial systems through electronic payments platforms and savings and credit supply technological platforms. Moreover, with the help of digital solutions, entrepreneurs and businesses can reconsider their business models which can be more competitive, sustainable, and better connected to other sectors of the economy in this way. The fintech has impacts beyond the financial sector and affects the real sector and households, initiating 
changes in business models across market segments. A good example for it Kenya, where blockchain made the efficient verification of property records and transactions possible, and also enabled expanded access to credit in some previously informal sectors of the economy [16].

Based on finance 4.0 technologies, there are very good opportunities for job creation in Africa. Mobile technologies and services generated 9 percent of GDP in sub-Saharan Africa and supported almost 2,05 million jobs (of which 650.000 formal jobs and 1,4 million in the informal spheres) in 2019. The GSM Association forecasts that by 2023, mobile's contribution will reach almost $\$ 185$ billion, 9.1 percent of GDP [19]. Given the informal sector is estimated to contribute 55 percent of subSaharan Africa's GDP [2] these tools can occur significant changes. Increased financial inclusion contributes to greater capital accumulation and investment, so a vast potential for employment creation.

Since creating jobs for the increasing youth population is an urgent priority in East African countries, governments are hesitating to support technologies that endanger current jobs. Some of the upcoming technologies will replace low-skilled workers with higher-skilled workers and constraining the involvement in the industry 4.0 to economies missing relevant skills [30]. Therefore, East African governments should invest in education and reskilling programs to ensure that the new technology support and not replaces labor.

\section{Employment in the context of finance 4.0 \\ Macro level effects}

If we investigate the effects of the technological jump in the finance sector on the macro-level, we can expect that improved financial inclusion through mobile payments supports a more intensive capital growth and investment, which is a very good base for employment expanding. Digital technologies generate substantial spillovers on local demand for services; it is projected that one additional technology job creates around five new jobs in the local sectors [14]. Since the larger part of the employment in developing countries is in micro, small, and medium enterprises, these firms are often supported by the governments or donor organizations for growth and job creation. Usually these interventions consist of provision of finance services, providing credit access, entrepreneurship training, business support services and wage subsidies [18]. Digitization could be a platform for the success of these interventions.

From a macro-financial approach, digitization can manage the typical problems of information asymmetry in the financial sector and in the labor market. Digital financial services provide useful database of individuals' financial transactions that financial institutions use to verify the creditability of their customers. Virtual savings account and virtual credit supply platforms, among others MKesho, M-Pesa, M-Shwari, Mobicash and Tangaza in Kenya facilitated the utilization of transactions and savings data as the base for micro credit pricing and evaluate credit risks. Information symmetry reduces the risk premium payments and pre-checking costs of credit transactions by the financial institutions. In this way, credit information sharing can help to promote access to affordable credit. This has improved access to credit by small entrepreneurs supporting them to keep or develop their companies so generating employment opportunities in the East African region.

\section{Micro level effects}

Based on the overview of evolution of financial services in East Africa we can draw some conclusions regarding the effects and mechanisms of the different development stages. The vibrant and technology-based financial activities boosted the number of clients and service providers and so more opportunities for employment. In the first stage (launch of electronic payments) there was a need for different new jobs at different levels (certain categories of agents). The developing network of agents reinforced the robust expansion in mobile devices based financial services (mobile money).

Garcia-Murillo and Velez-Ospina [15] argue that empowerment inspired by digitalization, including the greater and easier access to information and resources can help reduce the role of informal sector. In an economy with huge unemployment, digitization provides an easy opportunity for self-employment. This improves the informal market operations and increases labor absorption, but not in a formal way.

\section{Productivity}

The most important impact of digitization in the labor market is that it increases labor 
productivity [42]. Digitization improves total productivity by enhancing job matching hence the allocation of labor and skills to the most suitable opportunities in the market [9] and alleviates employees of monotonous repetitive working so they are able focus on more productive jobs. Digital platforms are able to reduce to costs of information search and improves chances for people who have problems in finding a job. In Kenya, some evidence from literature demonstrate a growth in labor productivity in the past decade [25] when the digital transformation was getting more significant.

In the financial sector, agency banking, that is based on the mobile phone-based financial services agents' network, has also created job opportunities across the region, overriding the likely job losses resulting from online banking. We expect that potential for digitization and net employment creation will show some positive results.

\section{Unemployment}

Wider and deeper access to information and sources can support diminish the informal sectors in the East African economies; in economies characterized by huge unemployment rate, digitization provides an easy solution for self-employment. This could improve the informal market operations and increases workforce absorption.

\section{CONCLUSIONS}

East African region remains one of the fastest-growing regions in the world, however high unemployment and high poverty rate is still a problem to be solved. The region shows a high level of entrepreneurial activity compared to other parts of Africa. With a well-focused policy support framework and a advantageous economic environment, including the spread of new industry and finance 4.0, the region could manage the problems of unemployment poverty.

With affordable and stable finance 4.0 solutions and a strong institutional framework, East African enterprises can reduce poverty, increase employment and promote inclusive growth by providing practical solutions through value-added products and services, enhancing GDP growth in this way.

Our expectation is that industry 4.0 and IoT initiatives will empower small (including rural) business owners in Africa, whereby the data based software and analytical solutions will be available on their smart devices; this will have an effect of better cooperation among stakeholders along the whole value chain. Moreover, connectivity will support their daily business through acceptance of digital payment methods and getting more information on their customers so they will be able to develop tailor-made marketing strategies based on the collected data. This will result in a much better-established business. Furthermore, small business runners will have better chances to apply for bank loans, as they have unquestionable, reliable data of their business processes and cash flow accounting.

\section{REFERENCES}

1. AFRICAN DEVELOPMENT BANK. Eastern Africa's Manufacturing Sector. Promoting Technology, Innovation, Productivity and Linkages: Tanzania Country Report. Nairobi, Kenya, 2014. 48 p.

[cited 21 october 2020]. Available:

https://www.afdb.org/fileadmin/uploads/afdb/Documents/Generic-

Documents/Eastern_Africa\%E2\%80\%99s_Manufacturing_Sector_-_Promoting_ Technology_-

_Tanzania_country_report_November_2014.pdf

2. AFRICAN DEVELOPMENT BANK. East Africa Economic Outlook 2020 - Coping with the COVID19 Pandemic. 2020.83 p. [cited 28 october 2020]. Available:

https://www.afdb.org/en/documents/east-africa-economic-outlook-2020-coping-covid-19pandemic

3. ALALOUL, W. S. et al. Industrial revolution 4.0 in the construction industry: challenges and opportunities for stakeholders. In: Ain Shams Engineering Journal. 2020, vol. 11, no. 1, pp. 225230. ISSN 2090-4479.

4. AMADOU, N. R. et al. FinTech in Sub-Saharan African Countries A Game Changer? International Monetary Fund, Africa Dept. 2019 [cited 15 october 2020]. Available:

https://www.imf.org/ /media/Files/Publications/DP/2019/English/FTSSACEA.ashx 
5. SVEIN, A. Regulatory and Supervisory Issues from FinTech. Cambridge Centre for Alternative Finance Conference. 2017, 29 june [cited 20 may 2020]. Available: https://www.fsb.org/wpcontent/uploads/Cambridge-Centre-for-Alternative-Finance-Regulatory-and-SupervisoryIssues-from-FinTech.pdf

6. BANGA, K., VELDE, D. Skill Needs for the Future. Pathways for Prosperity Commission. In: Background Paper Series. Oxford, United Kingdom. 2018, no. 10, august. 35 p.

7. BONGOMIN, O. et al. Sustainable and Dynamic Competitiveness towards Technological Leadership of Industry 4.0: Implications for East African Community. In: Journal of Engineering. 2020, june, pp.1-22. DOI: 10.1155/2020/8545281

8. CAMBRIDGE CENTRE FOR ALTERNATIVE FINANCE. The Africa and Middle East Alternative Finance Benchmarking Report. Cambridge University Press. Cambridge, 2017, february, 64 p. [cited 22 october 2020]. Available: https://www.jbs.cam.ac.uk/wpcontent/uploads/2020/08/2017-ccaf-africa-middle-east-alternative-finance-report.pdf

9. CHEN, C., HAYMON, M. Realizing the Potential of Digital Job-seeking Platforms. In: CHANDY, L., ed. The Future of Work in the Developing World. Brookings Blum Roundtable 2016 PostConference Report. Washington DC: Brookings Institution, Global Economy and Development Program, 2016, august, pp. 31-40. [cited 29 october 2020]. Available: https://www.brookings.edu/wp-content/uploads/2017/01/global_20170131_future-ofwork.pdf

10. DEMIRGUC-KUNT, A. et al. Global Findex Database 2017: Measuring Financial Inclusion and the Fintech Revolution. Washington: World Bank, 2018 [cited 14 november 2020]. Available: www.openknowledge.worldbank.org/handle/10986/29510

11. EAST AFRICAN COMMINITY. East African Community Industrialisation Policy 2012-2032. 2012. 31 p. [cited 23 october 2020]. Available:

http://repository.eac.int/bitstream/handle/11671/539/Final\%20\%20EAC\%20Industrializati on $\% 20$ Policy.pdf?sequence $=1$ \&isAllowed $=y$

12. HAMDI, el S., OUDANI, M., ABOUABDELLAH, A. Morocco's readiness to industry 4.0. In: BOUHLEL, M., ROVETTA, S., eds. Proceedings of the 8th International Conference on Science of Electronics, Technologies of Information and Telecommunications (SETIT'18). 2020, vol. 1, pp. 463-472. ISBN 978-3-030-21004-5. DOI: 10.1007/978-3-030-21005-2_44

13. FOWLER, M., RAUSCHENDORFER, J. Agro-industrialisation in Uganda: current status, future prospects and possible solutions to pressing challenges. International Growth Center. 2019, november, 25 p. [cited 12 october 2020]. Available: https://www.theigc.org/wpcontent/uploads/2019/11/Fowler-and-Rauschendorfer-2019-Working-paper-v2.pdf

14. FREY, C., RAHBARI, E. Technology at work: How the digital revolution is reshaping the global workforce. 2016, 25 march [cited 11 november 2020]. Available: https://voxeu.org/article/howdigital-revolution-reshaping-global-workforce

15. GARCIA-MURILLO, M., VELEZ-OSPINA, J. A. ICTs and the Informal Economy: Mobile and Broadband roles. In: Digital Policy, Regulation and Governance. 2017, vol. 19, issue 1, pp. 58-76. ISSN 2398-5038 [cited 05 october 2020]. Available: https://doi.org/10.1108/DPRG-02-20160004

16. GEBRE, S. Blockchain opens up Kenya's $\$ 20$ billion informal economy. Bloomberg, 2018, 13 june [cited 15 november 2020]. Available: https://www.bloomberg.com/news/articles/2018-0614/blockchain-is-opening-up-kenya-s-20-billion-informal-economy

17. GILLWALD, A. et al. State of ICT in Uganda. In: Policy Paper. Series 5. The State of ICT in Uganda. 2019, no. 8, may [cited 05 november 2020]. Available: https://researchictafrica.net/2019_afteraccess-the-state-of-ict-in-uganda/

18. GRIMM, M. What Interventions Create Jobs? A Review of the Evidence. In: CHANDY, L., ed. The Future of Work in the Developing World. Brookings Blum Roundtable 2016 Post-Conference Report. Washington DC: Brookings Institution, Global Economy and Development Program. 2016, august, pp. 59-67 [cited 13 november 2020]. Available: https://www.brookings.edu/wpcontent/uploads/2017/01/global_20170131_future-of-work.pdf 
19. GSM ASSOCIATION. The Mobile Economy: Sub-Saharan Africa 2019. London. 2020 [cited 10 november 2020]. Available: https://www.gsma.com/mobilefordevelopment/mobilemoney/industry-data-and-insights/

20. HE, D. et al. Fintech and Financial Services: Initial Considerations. Staff Discussion Note 17/05. International Monetary Fund. Washington, 2017, 19 june [cited 14 november 2020]. Available: https://www.imf.org/en/Publications/Staff-Discussion-Notes/Issues/2017/06/16/Fintechand-Financial-Services-Initial-Considerations-44985

21. INTERNATIONAL MONETARY FUND. Financial Access Survey. 2016 [cited 14 november 2020]. Available: https://data.imf.org/?sk=E5DCAB7E-A5CA-4892-A6EA-598B5463A34C

22. INTERNATIONAL TRADE CENTRE. Creative Industries in Rwanda: Digital Paths to Global Markets. Geneva, 2019, may. 50 p. [cited 28 october 2020]. Available:

https://www.intracen.org/uploadedFiles/intracenorg/Content/Publications/Rwanda\%20Digit al\%20exports_final_Low-res.pdf

23. KANOS, D., HEITZIG, C. Figures of the week: Regional heterogeneity in Africa's economic growth predicted to subside. Brookings, Thursday, 2020, 30 july [cited 29 october 2020]. Available: https://www.brookings.edu/blog/africa-in-focus/2020/07/30/figures-of-the-week-regionalheterogeneity-in-africas-economic-growth-predicted-to-subside/

24. KIMENYI, M., MWEGA, F., NDUNG'U, N. Economic Growth, Labour Market Dynamics, and Prospects for a Demographic Dividend. In: BHORAT, H., TARP, F., eds. Africa's Lions: Growth Traps and Opportunities for Six African Economies. Washington D.C.: Brookings Institution, Africa Growth Initiative, 2016 pp. 109-144. ISBN 978-0-8157-2949-5 [cited 11 october 2020]. Available:

https://library.oapen.org/bitstream/handle/20.500.12657/30692/644190.pdf?sequence=1\&is Allowed=y

25. KRESOVA, D. Can the Fourth Industrial Revolution-Industry 4.0-Hold the Future for Africa's Industrialisation? Case Study of Kenya. LUP Student Papers. Lund University. Sweden, 2019. 89 p. [cited 31 october 2020]. Available: http://lup.lub.lu.se/luur/download?func =downloadFile\&recordOId=8993841\&fileOId=8993856

26. LEGATUM INSTITUTE. The Africa Prosperity Report 2019/20. The Legatum Institute. London, 2020, january. 162 p. ISBN 9781911125556 [cited 26 october 2020]. Available: https://li.com/wp-content/uploads/2020/01/The-Africa-Prosperity-Report-2020.pdf

27. MANDA, M. I., BEN DHAOU, S. Responding to the challenges and opportunities in the 4 th industrial revolution in developing countries. In: Proceedings of the 12th International Conference on Theory and Practice of Electronic Governance ICEGOV, april 2019. New York, 2019, pp. 244-253. ISBN 978-1-4503-6644-1 [cited 21 october 2020]. Available: https://dl.acm.org/doi/proceedings/10.1145/3326365

28. MCKINSEY GLOBAL INSTITUTE. Digital finance for all: powering inclusive growth in emerging economies. McKinsey \& Company. 2016, september [cited 21 october 2020]. Available: https://appgfintech.org.uk/reports/mckinsey-global-institute-digital-finance/

29. MINISTRY OF TRADE AND INDUSTRY. Made in Rwanda Policy. 2017, november. 41 p. [cited 29 october 2020]. Available:

https://rwandatrade.rw/media/2017\%20MINICOM\%20Made\%20in\%20Rwanda\%20Policy\% 20(1).pdf

30. NAUDÉ, W. Entrepreneurship, education and the fourth industrial revolution in Africa. IZA Institute of Labor Economics. Discussion Paper 10855. Bonn, Germany, 2017. 22 p. [cited 12 november 2020]. Available: http://ftp.iza.org/dp10855.pdf

31. NDUNG'U, N. Digital Technology and State Capacity in Kenya. In: CGD Policy Paper. Washington DC, USA, 2019, no 154, august 2019 [cited 31 october 2020]. Available:

https://www.researchgate.net/publication/342353169_Digital_Technology_and_State_Capacit y_in_Kenya

32. NEWFARMER, R., PAGE, J., TARP, F. Industries without Smokestacks: Industrialization in Africa Reconsidered. WIDER Studies in Development Economics. Oxford University Press. Oxford, 2018. 451 p. ISBN 978-0-19-882188-5. 
33. NIELSEN RESEARCH. Digital Deposits: Mobile Banking Around the World. 2016, 18 october [cited 11 october 2020]. Available:

https://www.nielsen.com/us/en/insights/article/2016/digital-deposits-mobile-bankingaround-the-world/

34. OJOK, D., MUKHONE, B., ENYWARU, P. Managing the 4th Industrial Revolution in East Africa: Insights from the First Kampala Digitalization Forum. Ministry of ICT, National Guidance, Konrad Adenauer Stiftung. Kampala, Uganda, 2018. 51 p. [cited 31 october 2020]. Available: https://ict.go.ug/wp-content/uploads/2019/04/Kampala-Digitalization-ConferenceReport.pdf

35. ONYANGO, F. E. V., KESA, H. The fourth industrial revolution: implications for hotels in South Africa and Kenya. In: Tourism: An International Interdisciplinary Journal. 2018, vol. 66, no. 3, pp. 349-353 [cited 31 october 2020]. Available: https://hrcak.srce.hr/206166

36. SALAM, U. et al. Tanzania Case Study: Rapid Technological Change - Challenges and Opportunities. Final Report. Pathways for Prosperity Commission. In: Background Paper Series. Oxford, UK, 2018, no. 7 [cited 30 october 2020]. Available: https://pathwayscommission.bsg.ox.ac.uk/Tanzania-case-study

37. SKAN, J., DICKERSON, J., GAGLIARDI, L. Fintech and the Evolving Landscape: Landing Points for the Industry. Dublin, Ireland: Accenture, 2016. [cited 22 october 2020]. Available: https://www.accenture.com/t20161011T031409Z_w__/pl-en/_acnmedia/PDF-15/AccentureFintech-Evolving-Landscape.pdf

38. STEFANUK, A. Industry 4.0 And Its Impact On The Financial Services. 2020, 11 february [cited 22 october 2020]. Available: https://fintechweekly.com/magazine/articles/industry-4-0-and-itsimpact-on-the-financial-services

39. TARRÓSY, I. Africa's Urban Revolution. 2017. In: Afrika Tanulmányok. 2017, vol. 11, no. 3-4, pp. 91-94.

40. TECHNOPOLIS, RESEARCH ICT AFRICA. Tambourine Innovation Ventures. Potential of the Fourth Industrial Revolution in Africa. Study on Unlocking the Potential of the Fourth Industrial Revolution in Africa. Abidjan, Cote d'Ivoire. 2019, october [cited 23 october 2020]. Available: https://www.technopolis-group.com/wp-content/uploads/2020/02/Potential-of-the-fourthindustrial-revolution-in-Africa.pdf

41. UNITED NATIONS CONFERENCE ON TRADE AND DEVELOPMENT. East African Community Regional Integration: Trade and Gender Implications. Geneva, Switzerland: United Nations, 2018 [cited 30 october 2020]. Available: https://unctad.org/system/files/officialdocument/ditc2017d2_en.pdf

42. WORLD BANK. Digital Dividends: World Development. Report 2016. Washington, DC: World Bank, 2016 [cited 24 october 2020]. Available: https://www.worldbank.org/en/publication/wdr2016

43. WORLD BANK. Republic of Burundi Addressing Fragility and Demographic Challenges to Reduce Poverty and Boost Sustainable Growth. Report. Washington, DC: World Bank, 2018 [cited 24 october 2020]. Available: https://openknowledge.worldbank.org/handle/10986/30056

44. WORLD BANK. The World Bank in Africa. 2020 [cited 24 october 2020]. Available: https://www.worldbank.org/en/region/afr/overview\#2

\section{ARTICLE HISTORY}

Received 15 May 2020

Accepted 27 November 2020 